\title{
Hypoalbuminemia is an Important Risk Factor for Surgical Wound Healing
}

\author{
Authors \\ Dr Harekrishna Majhi*, Dr Pramit Ballav Panigrahi, \\ Dr Abinasha Mohapatra, Srimanta Mahapatra
}

Department of Surgery, Veer Surrendra Sai Institute of Medical Science and Research, Burla,

Odisha, India, 768017

*Corresponding Author

Dr Harekrishna Majhi

Associate Professor, Department of Surgery, Veer Surrendra Sai Institute of Medical Science and Research,

Burla,Odish, India,768017

\begin{abstract}
Introduction: This retrospective study used serum albumin as the only indicator of nutritional status for patients who are admitted for elective or emergency surgery. Serum albumin level is affected by insulin, thyroid hormones, inflammatory cytokines, hypermetabolism, malabsorption, intravascular volume overload. If the deficit factors could be identified and corrected in pre-operative period, the chances of wound healing related complications (like wound infection, wound dehiscence, and anastomotic leak) will be reduced.

Aim: To study effect of serum albumin level in abdominal wound healing and related complications like wound infection, wound dehiscence and anastomotic leak.

Materials and Methods: The study is conducted in surgery department, V.S.S. institute of medical science and research, Sambalpur, Odisha. A total of 150 patients were studied over a period of 5 months and were evaluated for serum albumin and the wound related complications.

Results: Hypoalbuminemics are more prone to develop wound related complications than normoalbuminemics.

Conclusion: Serum albumin levels can be considered to be one of the best predictors for the wound related complications.
\end{abstract}

\section{Introduction}

The number of patients admitted for surgery with hypoalbuminemia and malnutrition have more adverse effects on morbidity and mortality, which was first recognized by Hippocrates many century ago. Since then nutrition and serum protein level deserves a vital role in pre and post-operative field. Out of which serum albumin level is one of the best indicators of nutritional status. The surgical wounds, bedsores, and anastomotic sites are weak points in presence of malnutrition and hypoalbuminemia, which results in future complications and dehiscence ${ }^{[2]}$. Out of a varieties of nutritional indices are available for predicting patient's outcome, serum albumin is most readily available, clinically useful, one of the best prognostic indicator than anthropometric markers of nutritional status. Serum albumin level greater than $3.5 \mathrm{mg} / \mathrm{dl}$ suggests adequate protein stores, decreased risk of morbidity ${ }^{[1]}$. If increased needs 
are not met dietary or therapeutic sources, then visceral protein stores are depleted resulting subnormal function of organ system, gastrointenstinal malabsorption, decreased immune response, decreased hepatic protein synthesis ${ }^{[3]}$. Plasma proteins support tissues repair by metabolic as well as functional activities i.e. they directly facilitate wound healing by (i) providing carbohydrates, lipids and aminoacids in a usuable form as biosynthetic precussors and energetic substrates, (ii) transport of trace metal co-factors involved in various wound repair processes, (iii) adhesion of regenerating tissues, (iv) modulation of rate of structural protein synthesis, (v) alignment of collagen subunits, (vi) organization of cellular elements for wound repair, (vii) prevention of autoimmune reaction, (viii) hormone transport and local modulation of hormonal effects, (ix) neutralization of the potentially toxic products of inflammatory response, and (x) inhibition of microbial invasion and colonization.

\section{Aims and Objective}

To study the effect of serum albumin level on abdominal wound healing and it"s related complications like wound infection, wound dehiscence, anastomotic leak by comparing values between various patient groups.

\section{Material and Methods}

Source of Data - Patient admitted in surgery department, V.S.S. institute of medical science and research, Sambalpur, Odisha for major elective or emergency surgery between August 2019 to December 2019.

\section{Calculated Sample Size $-\mathrm{n}=150$}

Inclusion Criteria: Patients who are admitted for any elective or emergency surgery under surgery department, V.S.S. institute of medical science and research, Sambalpur, Odisha.

Exclusion Criteria: Patients who had jaundice, severe anaemia less than $7 \mathrm{~g} / \mathrm{dl}$, chronic renal disease, and patients on steroids/chemotherapy.
No patients who underwent blood transfusion or monitored less than 4 weeks are included.

\section{Method of Collection of Data}

Details of cases were recorded including history and clinical examination.

Investigation - all routine blood tests, and serum albumin was estimated on the day of admission and on every $5^{\text {th }}$ post operative days

Statistical Analyzed: The data was analyzed by Z-test. P value $<0.05$ was considered statistically significant and $\mathrm{P}$ value $>0.05$ was statistically insignificant.

\section{Results}

The study was conducted on 150 patients, aged between 4-80 years, who underwent any major elective or emergency surgery in V.S.S. institute of medical science and research, Sambalpur, Odisha from August 2019 to December 2019. Among the 150 patients, 47 patients were having serum albumin levels more than $3.5 \mathrm{~g} / \mathrm{dl}$ and 83 patients were having serum albumin less than 3.5 $\mathrm{g} / \mathrm{dl}$

Table 1: Sex Distribution

\begin{tabular}{|l|c|c|}
\hline Sex & Number & Percentage (\%) \\
\hline Male(M) & 92 & $61.33 \%$ \\
\hline Female(F) & 58 & $38.37 \%$ \\
\hline
\end{tabular}

Of the 150 patients studied, $61.33 \%$ were male and $38.37 \%$ were female.

Table 2: Age distribution

\begin{tabular}{|l|c|}
\hline Age in years & Total number \\
\hline$<10$ & 5 \\
\hline $11-20$ & 21 \\
\hline $21-30$ & 19 \\
\hline $31-40$ & 38 \\
\hline $41-50$ & 20 \\
\hline $51-60$ & 28 \\
\hline $61-70$ & 10 \\
\hline$>70$ & 9 \\
\hline Total & 150 \\
\hline
\end{tabular}

Out of 150 patients the age varied from 4-80 years. The number of patients were lowest and highest in the age group $<10$ years and 31 to 40 years respectively. 
Table 3: Protein status in pre and post-operative period

\begin{tabular}{|c|c|c|}
\hline $\begin{array}{l}\text { Serum albumin } \\
\text { level }(\mathrm{g} / \mathrm{dl})\end{array}$ & $\begin{array}{c}\text { Pre-operative } \\
\text { period (patients) }\end{array}$ & $\begin{array}{c}\text { Post-operative } \\
\text { period (patients) }\end{array}$ \\
\hline$<3.5$ & 43 & 96 \\
\hline$>3.5$ & 107 & 54 \\
\hline
\end{tabular}

Table 4: Post operative outcome

\begin{tabular}{|l|c|c|}
\hline & $<3.5 \mathrm{~g} / \mathrm{dl}$ & $>3.5 \mathrm{~g} / \mathrm{dl}$ \\
\hline Post operative complications & 38 & 5 \\
\hline No complication & 58 & 49 \\
\hline Total & 96 & 54 \\
\hline
\end{tabular}

Out of 96 patients with hypoalbuminemia 38 patients developed wound related complications and 5 patients with normal albumin levels developed wound related complications. The $\mathrm{p}$ value is 0.000217 .

The various complications were wound infection in 28 patients $(73.68 \%)$, wound dehiscence in 6 cases (15.79\%), anastomotic leak in 4 cases $(10.53 \%)$ in hypoalbuminemic group. Whereas 4 patients developed wound infection (80\%) and 1 patient developed anastomotic leak $(20 \%)$ in other group.

Table 5: Level of Albumin and post operative outcome

\begin{tabular}{|l|c|c|c|}
\hline $\begin{array}{l}\text { Serum } \\
\text { albumin g/dl }\end{array}$ & $\begin{array}{c}\text { Wond } \\
\text { infection }\end{array}$ & $\begin{array}{c}\text { Wound } \\
\text { dehiscence }\end{array}$ & $\begin{array}{c}\text { Anastomosis } \\
\text { leak }\end{array}$ \\
\hline$<3.5(96)$ & 28 & 6 & 4 \\
\hline$>3.5(54)$ & 4 & - & 1 \\
\hline
\end{tabular}

It was observed that the rate of complications were more in patients with serum albumin levels less than $3.5 \mathrm{~g} / \mathrm{dl}$. However in this study there was no mortality.

\section{Discussion}

Pre-operative nutritional assessment is an important indicator for localizing patients who have post-operative complication risks. Out of several nutritional indices available for predicting patient's outcome, pre-operative serum albumin level was used in our study for nutritional assessment.
Table 6: Significance of serum albumin levels in predicting postoperative outcome

\begin{tabular}{|l|c|c|}
\hline Study name & $\begin{array}{c}\text { Serum albumin g/dl } \\
\text { associated with increased } \\
\text { complications }\end{array}$ & p-value \\
\hline Vincent et al $^{[4]}$ & $<3$ & $<0.005$ \\
\hline Golub et al $^{[5]}$ & $<3$ & $<0.05$ \\
\hline Brown et al $^{[7]}$ & $<3$ & $<0.05$ \\
\hline Foley et al $^{[10]}$ & $<2.5$ & $<0.001$ \\
\hline Nagachinta et al $^{[9]}$ & $<3.9$ & $<0.001$ \\
\hline Present study & $<3.5$ & $<0.05$ \\
\hline
\end{tabular}

Serum albumin level less than $3 \mathrm{~g} / \mathrm{dl}$ was associated with increased post-operative morbidity and mortality according to studies done by Vincent et $\mathrm{al}^{[4]}$, Golub et $\mathrm{al}^{[5]}$, Wojtsiak et $\mathrm{al}^{[6]}$, Brown et $\mathrm{al}^{[7]}$, Mullen et $\mathrm{al}^{[8]}$.

Our study shows similar results $(\mathrm{p}<0.05)$, patient with serum albumin less than $3 \mathrm{~g} / \mathrm{dl}$ had more post-operative complication. Gibbs et $\mathrm{al}^{[2]}$ observed that a decrease in serum albumin from greater than $4.6 \mathrm{~g} / \mathrm{dl}$ to less than $2.1 \mathrm{~g} / \mathrm{dl}$ (p < 0.001) was associated with an increase in morbidity and mortality. Nagachinta et $\mathrm{al}^{[9]}$ also found an association between serum albumin less than $3.9 \mathrm{~g} / \mathrm{dl}$ and wound infection. According to Foley et $\mathrm{al}^{[10]}$ post-operative complication rate was higher when serum albumin was less than 2.5 $\mathrm{g} / \mathrm{dl}(\mathrm{p}<0.001)$.

In our study 150 patients, 54 patients had serum albumin of more than $3.5 \mathrm{~g} / \mathrm{dl}$. In this group the complication rates were significantly low. Only 5 patients developed complication, of which 4 had wound infection and 1 patient had suffered anastomotic leak. Where as in the other group 38 patients developed wound related complications. 28 patients had wound infection, 6 patients had wound dehiscence and 4 patients had anastomotic leak. The infection rate further increases as the protein level decreases. Of 43 patients with complications, 38 patients had serum albumin levels were less than $3.5 \mathrm{~g} / \mathrm{dl}$.

In contrast to above mentioned studies and our study, Ryan $\mathrm{JA}^{[11]}$ reported that there was no significant difference in wound infection rates with serum albumin greater than 3.4, 2.8-3.4, or less than $2.8 \mathrm{~g} / \mathrm{dl}$. Gherini et $\mathrm{al}^{[12]}$ showed that 
serum albumin values could not predict postoperative complication.

Engelman et $\mathrm{al}^{[13]}$ observed that serum albumin less than $2.5 \mathrm{~g} / \mathrm{dl}(\mathrm{p}<0.001)$ and BMI less than 20 $\mathrm{kg} / \mathrm{m} 2(\mathrm{p}<0.005)$ and greater than $30 \mathrm{~kg} / \mathrm{m} 2(\mathrm{p}<$ 0.005) was associated with increased postoperative complications. Joshi et $\mathrm{al}^{[14]}$ reported that post-operative mortality was higher when serum albumin was less than $3.2 \mathrm{~g} / \mathrm{dl}$ and BMI less than $20 \mathrm{~kg} / \mathrm{m} 2$ ( $\mathrm{p}<0.05)$.

Mullen et $\mathrm{al}^{[15]}$ reported that in the post-operative period being underweight was associated with increased mortality and obese individuals had more wound complications.

\section{Conclusion}

Our study shows that serum albumin is a good indicator of post-operative complications. The rate of complications were significantly high in patient with serum albumin less than $3.5 \mathrm{~g} / \mathrm{dl}$ and significant difference was found as compared to the patients with serum albumin more than 3.5 $\mathrm{g} / \mathrm{dl}$.

Because of half life of serum albumin is about 20 days and the body pool of serum albumin is large, the serum albumin level does not respond readily to the patient's nutritional status in the acute phase of severe illness or injury. Furthermore the serum albumin level is affected by a variety of factors such as insulin, thyroid hormones, inflammatory cytokines, hypermetabolism, malabsoption, and intravascular volume overload ${ }^{[16]}$.

Thus serum albumin is a good prognostic indicator because of its ability to detect proteinenergy malnutrition, which is not accompanied by lower body weight and may not be clinically recognizable, but is associated with significantly increased risk of morbidity and mortality.

\section{References}

1. Gibbs J, Cull W, Henderson W, Daley J, Hur K, Khuri SF. Preoperative Serum Albumin level as a predictor of operative mortality and morbidity. Arch Surg 1999; 134:36-42.
2. Heys SD, Simpson WG, Eremin O. Surgical nutrition. In: Paterson-Brown S, editor. Emergency surgery and critical care. 7th ed. London: WB Saunders, 1997; 55.

3. Williams JZ, Barbul A. Nutrition and wound healing. Surg Clin North Am 2003; 83:571.

4. Vincent JL, Dubois MJ, Navicks RJ, Wilkes MM. Hypoalbuminemia in acute illness: is there a rationale for intervention? Ann Surg, 2003; 237:319334.

5. Golub R, Sorrento JJ Jr, Cantu R Jr. Efficacy of albumin supplementation in the surgical intensive care unit: a prospective, randomized study. Crit Care Med 1997; 25: 249-252.

6. Wojtsjak SL, Brown RO, Roberson D. Effect of Hypoalbuminemia and parenteral nutrition on free water excretion and electrolyte-free water resorption. Crit Care Med 1992; 20:164-169.

7. Brown RO, Bradley JE, Bekemeyer WB. Effect of albumin supplementation during parenteral nutrition on hospital morbidity. Crit Care Med 1988; 16:1177-1182.

8. Mullen JL, Buzby GP, Waldman MT, Gertner MH, Hobbs CL, Rosato EF. Prediction of operative morbidity and mortality by preperative nutritional assessment. Surg Forum 1979; 30:80-82.

9. Nagachinta T, Stephens M, Reitz B. Risk factors for surgical wound infection following cardiac surgery. J Infect Dis 1957; 156: 967.

10. Foley EF, Borlase BC, Dzik WH. Albummin supplementation in the critically ill. A prospective, randomized trial. Arch Surg. 1990; 125:739-742.

11. Ryan JA, Taft DA. Preoperative nutritional assessmentdoes not predict morbidity and mortality in abdominal operations. Surg Forum 1980; 31:9698. 
12. Gherini S, Vaughn BK, Lombardi AV Jr, Mallory TH. Delayed wound healing and nutritional deficiencies after total hip arthroplasty. Clin Orthop Relat Res, 1993; 293:188-195.

13. Engleman DT, Adams DH, Byrne JG, Avanki SF, Collins JJ, Couper GS et al. Impact of BMI and Serum Albumin on morbidity and mortality after cardiac surgery. J Thorac Cardiovas Surg, 1999; 118: 866-873.

14. Joshi J, Shvkumaran S, Bhargav Y, Kansare B, Sharma RS. Perioperative management of the Geriatric patient. J Ind Aca Geri, 2006; 2:28-33.

15. Mullen JT, Davenport DL, Hutter MM, Hosokawa PW, Henderson WG, Khuri SF et al. Impact of BMI on perioperative outcome in patients undergoing major intra abdominal cancer surgery. Ann Surg Onco, 2008; 15:2164-2172.

16. Fuhrman MP ; The albumin nutrition concentration : separating myth from fact . Nutrition 18 : 199- 200, 2002. 